present instance we desire to draw their attention to an important paper by Prof. Flower, F.R.S. (Proc. Zoolog. Soc. 1876, p. 443), just published, on the differences between the skulls of the same two species. There are thirty skulls of single-horned rhinoceroses in the two great metropolitan zoological museums, and from a comparison of these Mr. Flower has been able to draw several important conclusions. One of these is that in the Indian Rhinoceros ( $R$, unicomis) the posterior termination of the bony nostrils (the mesopterygoid fossa) is considerably narrower than in the Javan species $(R$. sondaicus), at the same time that the vomer terminates behind by becoming lost, through fusion, in the pterygoid processes, instead of ending free, lamelliform, and pointed. In the Indian rhinoceros, also, the upper grinding teeth have a pattern which is easily distinguishable from that of the Javan animal, a peculiar little circular " accessory valley "being developed in the first and second molars of the former, not found in the latter. In the same paper $\mathrm{Mr}$. Flower also brings forward an interesting difference between the skulls of the single and double-horned rhinoceroses, the external auditory meatus being embraced below by the fusion of the post-glenoid and post-temporal processes of the squamosal portion of the temporal bone in the one group, whilst in the other these two processes remain separate, as in the horse and tapir. The African species agree with the two-horned Asiatic in this respect, so that the character separates the unicorn from the bicorn Rhinoceroses.

PASSERINE BIRDS. - Within a few pages of the paper above referred to is one by Mr. A. H. Garrod upon some of the peculiarities in the anatomy of Passerine Birds. The nature of the voice-organ is the point laid most stress upon. For a long time it has been known that there is a small section of the Passerine birds which has no muscular organ of voice that may be employed for singing. These all were supposed to inhabit America, although from the conformation of their wings, wherein they alone resemble the aberrant genera just mentioned, Herr Cabanis, of Berlin, as long ago as 1846 , predicted that the Old World Ant Thrushes (Pittida), lacked the voice organ. Mr. Garrod, from a dissection of several specimens of two species of Pitta, demonstrates that Cabanis was quite correct in his surmise, and that the voice-organ is absent in them. He also describes the same organ in the Lyre Bird of Australia (Menura superba), and in its diminutive and interesting ally Atrichia rufescens. The paper ends with an outline plan of the classification which introduces more than one novel feature.

\section{BAROMETRIC VARIATIONS}

T $N$ the "Notes," NATURE, vol. xiv. p. 464 , I see reference 1 is made to my results on this subject, and it is suggested that Geveral Myer's International observations will be of the greatest value in connection with the question whether there may not be some other attractive force than gravitation connected with these variations.

I had come to the conclusion nearly twenty years ago (see British Association Transactions for 1859) that the mean pressure of the atmosphere for the whole globe was probably less for July than for January. This conclusion was derived from observations made at a great number of stations in both hemispheres during these months in the same year (I844). A considerable part of the earth's surface was not covered by these stations. About a year ago I received from Gen. Myer a copy of the Bulletin of International Observations made on February 7 , I 875 , at 7 h. $35 \mathrm{~m}$. A.M., Washington Mean Time, and I was glad to see in such observations the means of making more complete comparisons of the mean barometric pressure for given instants on different days. It was only a few months later that I found I could obtain a sight of other Binlletins at the Meteorological Office. I had time, however, to compare only two Bulletins, that sent me by Gen. Myer for February 7 , and another for the 27 th of the same month (1875) which seemed to show a lower pressure generally than the first. Other investigations have prevented me from seeking for a larger series of Bulletins to carry out the comparisons; but it seems to me that the comparison then maje is sufficiently interesting to merit notice.

The mean barometric pressure at 7 h. $35 \mathrm{~m}$. A.M., Washington M.T., was found for each of the countries in the Bulletin, on each of the two days mentioned; the differences of these mean pressures were then taken; they are given, with the numbers of stations from which the results are obtained, in the following table:-

\begin{tabular}{|c|c|c|c|c|c|c|c|c|c|}
\hline \multicolumn{5}{|c|}{ Country. } & \multicolumn{3}{|c|}{$\begin{array}{l}\text { Number of } \\
\text { Stations. }\end{array}$} & \multirow{2}{*}{\multicolumn{2}{|c|}{ 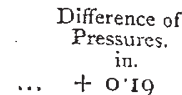 }} \\
\hline Russian Empir & & $\cdots$ & & & $\ldots$ & 23 & $\ldots$ & & \\
\hline Denmark ... & & $\cdots$ & & & $\ldots$ & 3 & $\ldots$ & ... & +0.21 \\
\hline Greenland, Ice & land, & & $\mathrm{Fat}$ & röe & $\ldots$ & 3 & $\ldots$ & $\ldots$ & -0.48 \\
\hline orway $\quad .$. & $\cdots$ & ... & $\ldots$ & $\ldots$ & ... & 3 & $\ldots$ & $\cdots$ & +0.33 \\
\hline ustria $\quad .$. & $\ldots$ & $\cdots$ & $\ldots$ & $\ldots$ & $\ldots$ & 12 & $\ldots$ & $\ldots$ & +0.06 \\
\hline Turkey ... & & & $\ldots$ & & $\ldots$ & 5 & $\ldots$ & $\cdots$ & +0.19 \\
\hline Mediterranean, & , Gib & oralta & & Corsica & & 3 & ... & $\ldots$ & +0.15 \\
\hline Germany $\ldots$ & $\ldots$ & $\cdots$ & $\ldots$ & $\ldots$ & $\ldots$ & $2 \mathrm{I}$ & $\ldots$ & $\ldots$ & +0.30 \\
\hline erland & $\ldots$ & $\cdots$ & $\cdots$ & $\ldots$ & $\ldots$ & 2 & $\ldots$ & $\ldots$ & +0.6 \\
\hline . $\quad \ldots$ & $\ldots$ & $\ldots$ & $\ldots$ & $\ldots$ & $\ldots$ & $x_{3}$ & $\ldots$ & $\ldots$ & +0.32 \\
\hline geria & $\ldots$ & .. & $\cdots$ & $\cdots$ & $\ldots$ & 9 & $\cdots$ & $\cdots$ & +0.27 \\
\hline Netherlands & $\ldots$ & $\cdots$ & ... & $\cdots$ & $\cdots$ & 4 & $\cdots$ & $\cdots$ & +052 \\
\hline Belgium $\quad \ldots$ & $\cdots$ & $\cdots$ & $\cdots$ & $\cdots$ & $\ldots$ & I & $\cdots$ & $\ldots$ & +0.55 \\
\hline$\ldots$ & $\ldots$ & $\ldots$ & $\ldots$ & $\ldots$ & $\ldots$ & $2 \mathrm{I}$ & $\ldots$ & $\ldots$ & +0.54 \\
\hline Spain... & $\ldots$ & $\ldots$ & $\ldots$ & $\ldots$ & $\ldots$ & I & $\ldots$ & $\cdots$ & +0.27 \\
\hline Portugal . .. & $\cdots$ & $\ldots$ & & $\ldots$ & $\ldots$ & I & $\ldots$ & $\ldots$ & +0.26 \\
\hline Great Britain a & and I & Trelan & & .. & $\cdots$ & $4 \mathrm{I}$ & $\cdots$ & $\ldots$ & +032 \\
\hline Canada $\quad \ldots$ & $\ldots$ & $\ldots$ & $\ldots$ & ... & $\ldots$ & is & $\ldots$ & $\ldots$ & +0.53 \\
\hline United States & $\ldots$ & .. & & .. & $\cdots$ & 96 & $\ldots$ & $\cdots$ & \\
\hline Indies & $\ldots$ & $\ldots$ & $\cdots$ & $\ldots$ & $\ldots$ & 7 & $\cdots$ & $\cdots$ & +0.09 \\
\hline Ceylon $\quad . .$. & & $\ldots$ & & $\ldots$ & $\ldots$ & I & $\ldots$ & $\ldots$ & +0.21 \\
\hline Cape of Good & Hop & 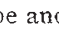 & & & & 2 & $\cdots$ & & 0.00 \\
\hline
\end{tabular}

It will be seen that, with the exception of the small area about Iceland, all the differences are positive; or the barometer stood higher on February 7,1875 , at $7 \mathrm{~h} .35 \mathrm{~m}$. A.M. W. M.T., than on the 27 th at the same hour. I have no doubt that when the investigation is made with the care it merits, much more marked results will be obtained. All these series, however, with the exception of the last two stations, are in the northern hemisphere; it is then of course possible that the atmosphere was playing at "hide and seek" with us, and had moved away to places for which no observations are at present forthcoming. There may also have been some difference in the amount of vapour in the air on these two days ; this I have not attempted to calculate, but for two days in February, in the northern hemisphere, it will probably be very small. ${ }^{1}$

In the first investigation already referred to, I had calculated the mean tension of vapour in the lowest stratum of the atmosphere for each station; this, it is now agreed, does not indicate the pressure of vapour on the barometer, but the result was that the vapour tension was greatest in July, whan the mean barometric pressure was least. A reason for the increased mean vapour tension for the whole globe in July will be found in Dove's result that the mean temperature of the whole atmosphere is greatest in that month. I shall probably take the liberty of returning to this subject.

JOHN ALLAN BROUN

I I see from the Bulletin in my possession (that for February 7 ) that the thermometer was, on the average, below zero (centigrade) in Europe, and from $10^{\circ}$ to $30^{\circ}$ below zero in America; the higher pressure on the 7 th could scarcely then be due to the vapour in the air. For any considerable Myer should contain the olserved. pressures for tions like those of Geveral tion to the sea-level) as well as the calculated ea-level pressures; since if, at tion to the sea-level) as well as the calculated : ea-level pressures; since if, at any high level station, the observed pressures are cractly the same on two
days, one of which has a higher temperature than the other, tr:e calculated day's, one of which has a higher temperature than the other, the calculated
pressures for the sea-level will differ, that for the lower temperature being pressures for the sea-level will differ, that for the lower temperature being
highest. The greatest mean error due to this cause in the present instance will not, in all probability, exceed to or inch. 